\title{
GROWTH KINETICS AND SURVIVAL OF LACTOBACILLUS ACIDOPHILUS IN BLACK RICE MILK
}

\author{
Serap Coşansu*, Samin Toupal, Özge Aslan \\ Department of Food Engineering, Engineering Faculty, Sakarya University, Sakarya, Turkey
}

Received / Geliş: 12.10.2021; Accepted / Kabul: 26.11.2021; Published online / Online bask1: 09.12.2021

Coşansu, S., Toupal, S., Aslan, Ö. (2021). Growth kinetics and survival of Lactobacillus acidophilus in black rice milk. GIDA (2021) 46 (6) 1440-1449 doi: 10.15237/gida.GD21132.

Coşansu, S., Toupal, S., Aslan, Ö. (2021). Lactobacillus acidophilus'un siyah pirinç sütünde gelişme kinetiği ve canlılığ1. GIDA (2021) 46 (6) 1440-1449 doi: 10.15237/gida.GD21132.

\begin{abstract}
The growth kinetics of Lactobacillus acidophilus in black rice milk, white rice milk and MRS Broth were calculated by applying the experimental data to the Gompertz equation using DataFit software. The survival of $L$ acidophilus in black rice and white rice milk was monitored during storage $\left(4^{\circ} \mathrm{C}, 20\right.$ days). The shortest lag phase duration $(1.45 \mathrm{~h})$ and the highest maximum population density $(7.48 \log \mathrm{CFU} / \mathrm{mL})$ were in black rice milk $(P<0.05)$. The generation time in black rice milk $(1.31 \mathrm{~h})$ was longer than in white rice milk $(0.58$ h) but shorter than in MRS Broth $(2.22 \mathrm{~h}, P<0.05)$. L acidophilus population declined in both milk at $4{ }^{\circ} \mathrm{C}$, but higher in black rice than white rice at the end of the storage period. It was concluded that black rice supports the growth of L. acidophilus compared to white rice and MRS Broth while contributing to its survival during cold storage.
\end{abstract}

Keywords: probiotic, prebiotic, black rice, lag phase duration, generation time, Gompertz equation, DataFit

\section{LACTOBACILLUS ACIDOPHILUSUN SIYYAH PİRINÇ SÜTÜNDE GELİŞME KİNETİĞİ VE CANLILIĞI}

\section{ÖZ}

Lactobacillus acidophilus'un siyah pirinç sütü, beyaz pirinç sütü ve MRS Broth besiyerindeki gelişme kinetiği deneysel verilerin DataFit yazılımı kullanılarak Gompertz eşitliğine uygulanmasıyla hesaplanmıştır. Ayrıca, L. acidophilus'un siyah ve beyaz pirinç sütündeki canlılığı depolama $\left(4^{\circ} \mathrm{C}, 20\right.$ gün) süresince izlenmiştir. En kısa lag fazı süresi $(1.45 \mathrm{~h})$ ve en yüksek popülasyon yoğunluğu (7.48 $\log \mathrm{CFU} / \mathrm{mL})$ siyah pirinç sütünde belirlenmiştir $(P<0.05)$. Jenerasyon süresinin siyah pirinç sütünde $(1.31 \mathrm{~h})$ beyaz pirinç sütündekinden $(0.58 \mathrm{~h})$ daha uzun, ancak MRS Broth besiyerindekinden $(2.22$ h) daha kısa olduğu tespit edilmiştir $(P<0.05)$. L. acidophilus popülasyonu her iki sütte de $4^{\circ} \mathrm{C}^{\prime} \mathrm{de}$ azalmış, ancak depolama sonunda siyah pirinç sütünde beyaz pirinç sütündekinden daha yüksek olduğu gözlenmiştir. Siyah pirinç sütünün beyaz pirinç sütü ve MRS Broth besiyerine göre $L$. acidophilus'un gelişimi desteklediği ve soğukta depolama süresince canlılı̆̆ına katkıda bulunduğu sonucuna varilmıştır.

Anahtar kelimeler: probiyotik, prebiyotik, siyah pirinç, lag faz süresi, jenerasyon süresi, Gompertz eşitliği, DataFit

${ }^{*}$ Corresponding author / Yazışmalardan sorumlu yazar

fin: scosansu@sakarya.edu.tr

(D): (+90) 2642955924

且: (+90) 2642955601

Serap Coşansu; ORCID no: 0000-0003-2875-1335

Samin Toupal; ORCID no: 0000-0002-6689-3222

Özge Aslan; ORCID no: 0000-0001-7730-0042 


\section{INTRODUCTION}

Probiotics are live microorganisms that provide health benefits to the host when given sufficient quantities (FAO/WHO, 2001). These microorganisms, mainly belonging to the Lactobacillus and Bifidobacterium genera, are live microbial food supplements that can improve consumer health by maintaining or improving the balance of the gut microbiota. Probiotics can help cure some health problems such as gastrointestinal infections, lactose intolerance, genitourinary infections, food allergies, and some bowel disorders (Figueroa-Gonzalez et al., 2011). Probiotics make an excellent environment for the smooth working of different metabolic activities within the digestive system generating proteins, carbohydrates, vitamins, and chemicals. Organic acids and proteolytic enzymes produced by lactic acid bacteria have suppressive effects on pathogenic intestinal bacteria (Indira et al., 2019). The clinical trials on the health benefits of probiotics have recently focused on gastrointestinal, skin, urinary tract, oral, and respiratory diseases (Aleixandre-Tudo et al., 2020). While probiotics are live microorganisms providing health benefits to the host, prebiotics are specific food components that support the growth or desired activities of beneficial microbes (Cremon et al., 2018). The prebiotic food components include non-digestible carbohydrates such as polysaccharides, oligosaccharides, etc. (de Paulo Farias et al., 2019).

The dairy products, such as yogurt, milk, cheese, kefir, etc., are common carrier foods for probiotic cultures; however, cereal, fruit, or vegetable-based products are considered potential carriers for these beneficial microorganisms (FigueroaGonzalez et al., 2011). People may avoid milkbased probiotic products due to high cholesterol content, lactose intolerance, diet style, milk protein allergy, or other reasons (Panghal et al., 2018). Hence, there is a trend to consume plantbased milk alternatives obtained from nuts, seeds, beans, and grains (Pimentel et al., 2021). The global market share for non-dairy milk alternatives is estimated to be almost 26 million U.S. Dollars in the next two years (Tangyu et al., 2019). The non-dairy probiotic products can be used as a therapeutic agent for lactose intolerance (Deng et al., 2015).

Rice, a major cereal crop worldwide, is a genetically diverse plant with thousands of varieties (Ito and Lacerda, 2019). Black rice is a pigmented rice variety rich in nutrients, including fiber, proteins, iron, vitamins, minerals, and essential trace elements (Sangma and Parameshwari, 2021). Paella, rice cakes, pancakes, fried rice, risotto, etc., are examples of foods that contain black rice in their recipes. Additionally, thanks to its high nutritional value, black rice can be included in the formula of different kinds of foods such as beverages, desserts, bread, and pasta (Ito and Lacerda, 2019).

Black rice is attractive for researchers due to its high nutritional and antioxidant characteristics. Anthocyanins, primary bioactive compounds in pigmented rice varieties, are one of the subclasses of plant phenolic compounds responsible for the purple, red and blue colors in plants (Khoo et al., 2017). Red cabbage, grapes, sweet potato, blood orange, black chokeberry, currants, some tropical fruits, etc., have anthocyanin contents. Recent clinical trials have demonstrated that regular consumption of anthocyanin-containing fruit extracts could positively modify the intestinal microbiota (Hester et al., 2018). It has been suggested that anthocyanins can be degraded by intestine microflora, resulting in other degradation products with beneficial effects on gut health (Hidalgo et al., 2012). Recent studies have shown that anthocyanins (Sun et al., 2018) and the fruit extracts rich in anthocyanin (Coman et al., 2018; Pallah et al., 2019) have a promotive impact on the growth of beneficial bacteria such as Bifidobacterium spp., Lactobacillus spp., etc. Furthermore, in an in vitro study (Zhu et al., 2018), anthocyanins and anthocyanin monomers derived from black rice displayed prebiotic activity and supported the growth of $L$. acidophilus and Bifidobacterium spp. Hence, black rice millk has the potential to be used in probiotic products due to its high nutritional value and the beneficial effects of black rice anthocyanins on probiotic bacteria. 
Therefore, the primary purpose of this study was to understand how black rice milk affects the growth kinetics of Lactobacillus acidophilus compared to white rice milk and MRS Broth. Besides, the survival of $L$. acidophilus in black rice milk and white rice milk during storage at $4^{\circ} \mathrm{C}$ was investigated.

\section{MATERIALS AND METHODS}

\section{Materials}

Black rice and white rice were purchased from a local market in Sakarya, Turkey. Lactobacillus acidophilus strain LA5 was obtained from $\mathrm{Chr}$. Hansen (İstanbul, Turkey).

\section{Rice milk preparation}

Rice milk was prepared according to the method described by Belewu et al. (2013). Black rice was soaked with tap water in a 1:3 ratio (rice to water) for two hours at ambient temperature. Then the rice slurry was cooked until the water was utterly absorbed and rice grains were softened. After waiting at ambient temperature for $15 \mathrm{~min}$, the cooked rice mash was diluted by adding water in a ratio of 1:2 (cooked rice: water) and homogenized for one min using a kitchen-type blender. Afterward, the rice slurry was drained using a clean cheesecloth. The same procedure was applied for the preparation of white rice milk. The rice milk samples were prepared freshly before each experiment.

\section{Preparation of Lactobacillus acidophilus} inoculum and inoculation of rice milk

L. acidophilus LA5 culture was activated twice in De Man Ragosa Sharpe (MRS) broth (Merck, Darmstadt, Germany) at $37^{\circ} \mathrm{C}$ for $24 \mathrm{~h}$. The active culture in MRS Broth was diluted using physiological saline $(0.85 \% \mathrm{NaCl})$. Five $\mathrm{ml}$ portions of black and white rice milk were transferred into two sets of sterile test tubes, and the third set of tubes were contained MRS Broth. Each tube was inoculated with $L$. acidophilus by pipetting $100 \mu \mathrm{L}$ of diluted inoculum to achieve $10^{4} \mathrm{CFU} / \mathrm{mL}$ final inoculation level. Then the tubes were incubated at $37^{\circ} \mathrm{C}$ for up to 40 hours. During incubation, at each predetermined sampling time $(0,2,46,8,10,14,16,18,20,22$, 24,30 , and $40 \mathrm{~h}$ ), one tube was removed from each sample group to determine L. acidophilus count and $\mathrm{pH}$ measurement.

\section{Determination of cell viability during cold storage}

One hundred $\mathrm{ml}$ portions of black rice milk and white rice milk were transferred into sterile jars. The freshly prepared milk samples were inoculated with L acidophilus at $10^{4} \mathrm{CFU} / \mathrm{mL}$ level and incubated at $37^{\circ} \mathrm{C}$ for $24 \mathrm{~h}$. Following incubation, jars were stored at $4^{\circ} \mathrm{C}$ for 20 days. Sampling was done on days $0,7,14$, and 20 to determine viable cell counts in black and white rice milk samples.

Microbial enumeration and $\mathrm{pH}$ measurement Samples were serially diluted using sterile saline solution $(0.85 \% \mathrm{NaCl})$ and spread plated onto MRS Agar. The plates were anaerobically incubated (Anaerocult C; Merck, Darmstadt, Germany) at $37^{\circ} \mathrm{C}$ for $72 \mathrm{~h}$ (Schillinger and Holzapfel, 2012). At each sampling time, $\mathrm{pH}$ values of samples were measured using a $\mathrm{pH}$ meter (Mettler-Toledo Seven Compact S210).

\section{Data analysis}

Two independent experiments were performed to calculate growth kinetics and to estimate cell viability during cold storage. The experimental data was applied to the Gompertz equation (Gibson et al., 1987) using DataFit software (DataFit for Windows version 9.1.32, Oakdale Engineering, Oakdale, PA, USA) to produce growth curves. The Gompertz equation was as follows:

$L(t)=A+C \times \exp \{-\exp [-B \times(t-M)]\}$

where $\mathrm{L}(\mathrm{t}), \log$ count of bacteria at time (h) $\mathrm{t}[\mathrm{log}$ $(\mathrm{CFU} / \mathrm{mL})] ; \mathrm{A}$, asymptotic log count of bacteria as time decreases indefinitely $[\log (\mathrm{CFU} / \mathrm{mL})]$; , asymptotic amount of growth that occurs as $\mathrm{t}$ increases indefinitely $[\log (\mathrm{CFU} / \mathrm{mL})] ; \mathrm{M}$, time at which the absolute growth rate is maximal (h); B, relative growth rate at $\mathrm{M}[\log (\mathrm{CFU} / \mathrm{mL}) / \mathrm{M}]$.

Lag Phase Duration (LPD), Generation Time (GT), Exponential Growth Rate (EGR), and Maximum Population Density (MPD) were calculated using Gompertz parameter values as 
described by Gibson et al. (1987) with the following equations:

$L P D=M-(1 / B)$

$G T=[\log (2)] e / B \times C$

$E G R=(B \times C) / e$

$M P D=A+C$

\section{Statistical analysis}

Analysis of variance (ANOVA) was performed using SPSS software (IBM SPSS Statistics for Windows, version 20.0). Duncan's multiple range test was applied to determine the differences $(P$ $<0.05)$.

\section{RESULTS AND DISCUSSION}

Figure 1 depicts the growth curves of $L$. acidophilus in black rice milk, white rice milk, and MRS Broth at $37^{\circ} \mathrm{C}$. The highest number $(7.97 \log \mathrm{CFU} / \mathrm{mL})$ was reached after 24-h incubation in black rice milk. In contrast, those were detected after 22 hours in white rice milk $(6.77 \log \mathrm{CFU} / \mathrm{mL})$ and MRS Broth (7.11 log CFU/mL). The population of the bacterium reduced slightly in all media starting the $24^{\text {th }}$ hour of incubation.

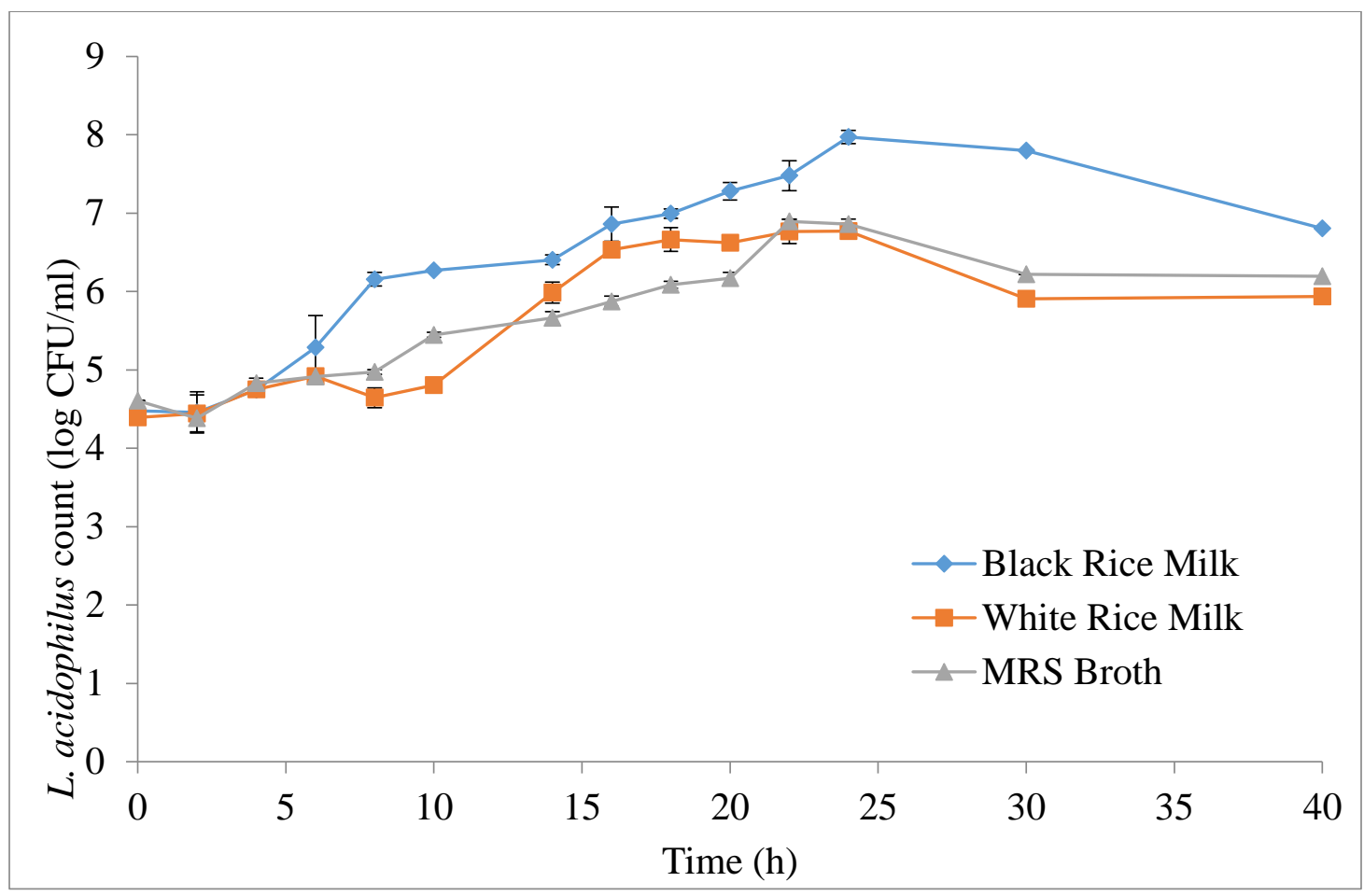

Figure 1. Growth of L. acidophilus in black rice milk, white rice milk, and MRS Broth incubated at $37^{\circ} \mathrm{C}$

The initial $\mathrm{pH}$ values of black rice milk, white rice milk, and MRS Broth were 6.60, 7.62, and 5.70, respectively (Figure 2). No significant reduction was observed in the $\mathrm{pH}$ value of white rice milk $(P>0.05)$ during the first $6 \mathrm{~h}$ of incubation. The $\mathrm{pH}$ value of white rice milk decreased to 4.86 after an 18-h incubation period when the $L$ acidopbilus population exceeded $6 \log \mathrm{CFU} / \mathrm{mL}$. The final $\mathrm{pH}$ value was 4.27 after $40 \mathrm{~h}$ incubation $(P<0.05)$. On the other hand, a milder reduction in the $\mathrm{pH}$ value of black rice milk was observed compared to white rice milk. Slight reductions in $\mathrm{pH}$ values of black rice milk were observed during the first $10 \mathrm{~h}(P>0.05)$ and then reduced gradually to 4.66 at the end of incubation $(P<0.05)$. The $\mathrm{pH}$ value of black rice milk was 4.95 after 22 -h incubation. Fewer changes were detected in $\mathrm{pH}$ values of MRS Broth than black rice milk and white rice milk $(P<0.05)$. The decrease was smaller than one unite after a 24-h incubation period, and the final $\mathrm{pH}$ value of MRS Broth was 4.39. After 40-h incubation, the $\Delta \mathrm{pH}$ values of black rice milk, white rice milk, and MRS Broth were calculated as $1.94,3.36$, and 1.31 , respectively. 


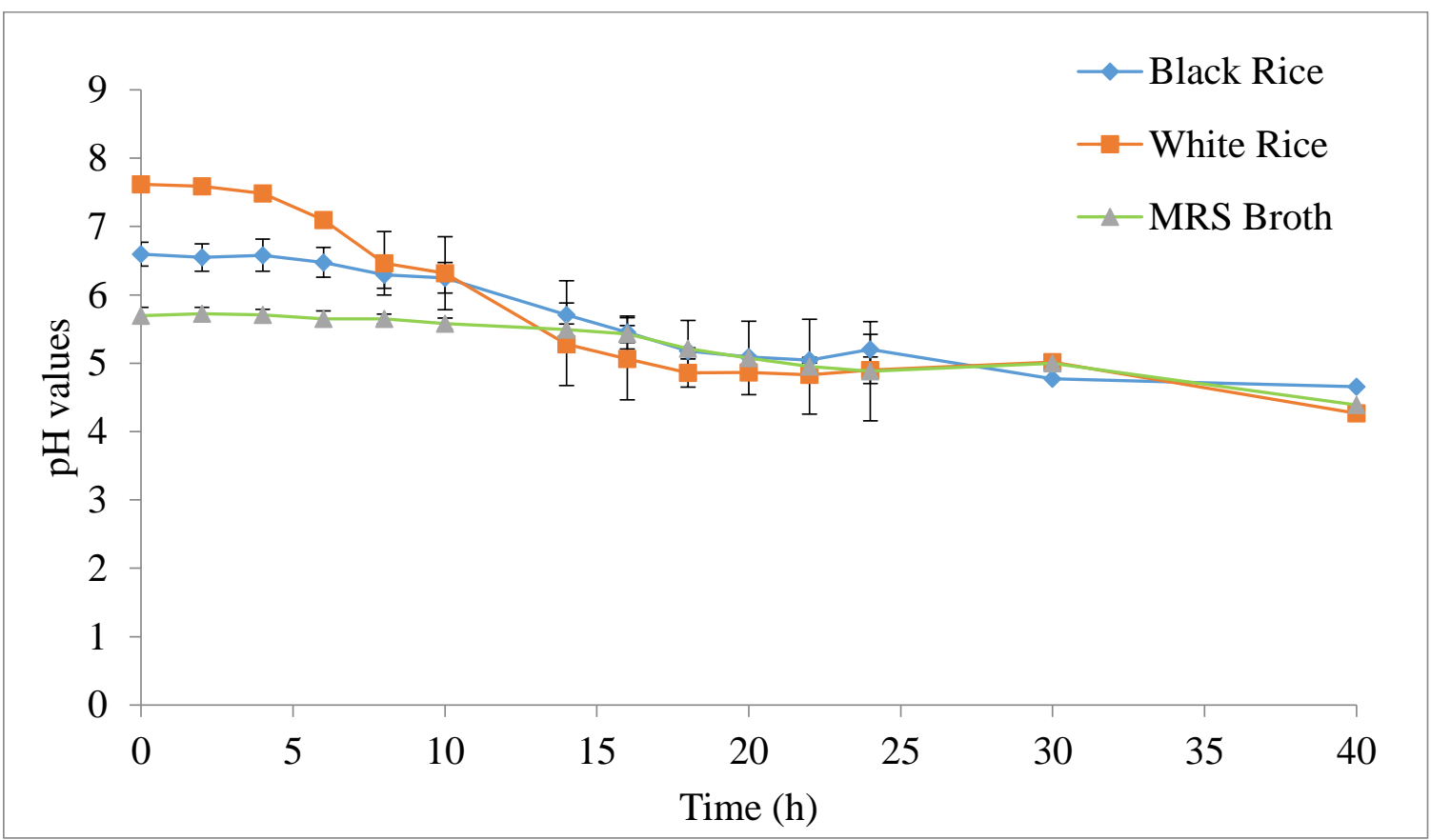

Figure 2. $\mathrm{pH}$ values of black rice milk, white rice milk, and MRS Broth fermented with $L$. acidophilus at $37^{\circ} \mathrm{C}$

Although the initial $\mathrm{pH}$ value of white rice milk was approximately one unit higher than black rice milk $(P<0.05)$, it reduced fast with a higher $\Delta \mathrm{pH}$ value at the end of incubation. The difference in $\mathrm{pH}$ changes may stem from the different chemical compositions of the two rice varieties. White rice varieties have higher carbohydrate and lower protein contents than black rice varieties (Ito and Lacerda, 2019; Sangma and Parameshwari, 2021). Therefore it may be speculated that the high fermentable carbohydrate content of white rice milk provided faster $\mathrm{pH}$ reduction. On the other hand, fewer $\mathrm{pH}$ reductions in MRS Broth than in black and white milk were not surprising because MRS Broth is a buffered culture medium (Anonymous, 2021).

The experimental data was applied to the Gompertz equation to calculate the growth kinetics of L. acidophilus. Figure 3 shows the model plots obtained by DataFit software. The coefficients of multiple determination $\left(r^{2}\right)$ were 0.93, 0.96 and 0.92 for black rice milk, white rice milk and MRS Broth, respectively. The growth kinetics calculated of $L$. acidophilus using
Gompertz parameter values are displayed in Table 1.

The lag phase duration (LPD) in white rice milk is more extended than in MRS Broth (twofold) and black rice milk ( 7.5 fold). The LPD was the shortest in black rice milk $(P<0.05)$. L acidophilus started to multiply in black rice milk following a 1.45-h LPD, while longer times were needed in MRS Broth (4.23 h) or white rice milk (10.94 h). The lag phase is defined as the adaptation period of bacterial cells to the new environment before initiating logarithmic growth (Swinnen et al., 2004). Since L. acidophilus cells grown in MRS Broth were used for inoculation, immediate initiation of exponential growth was expected. However, the LPD in MRS Broth calculated in this study was longer than in the previous studies. Harockova et al. (2020) reported 2.5 h LPD of L. acidophilus in MRS Broth. Considering the optimal $\mathrm{pH}$ range for the growth of $L$. acidophilus is 5.5-6.0 (Gomes and Malcata, 1999), the long LPD in white rice milk may be attributed to the high initial $\mathrm{pH}(7.62 \pm 0.07)$. The count of $L$. acidophilus started to increase after $10 \mathrm{~h}$ incubation when the $\mathrm{pH}$ value reduced to 6.32 (Figure 1 and 2). 

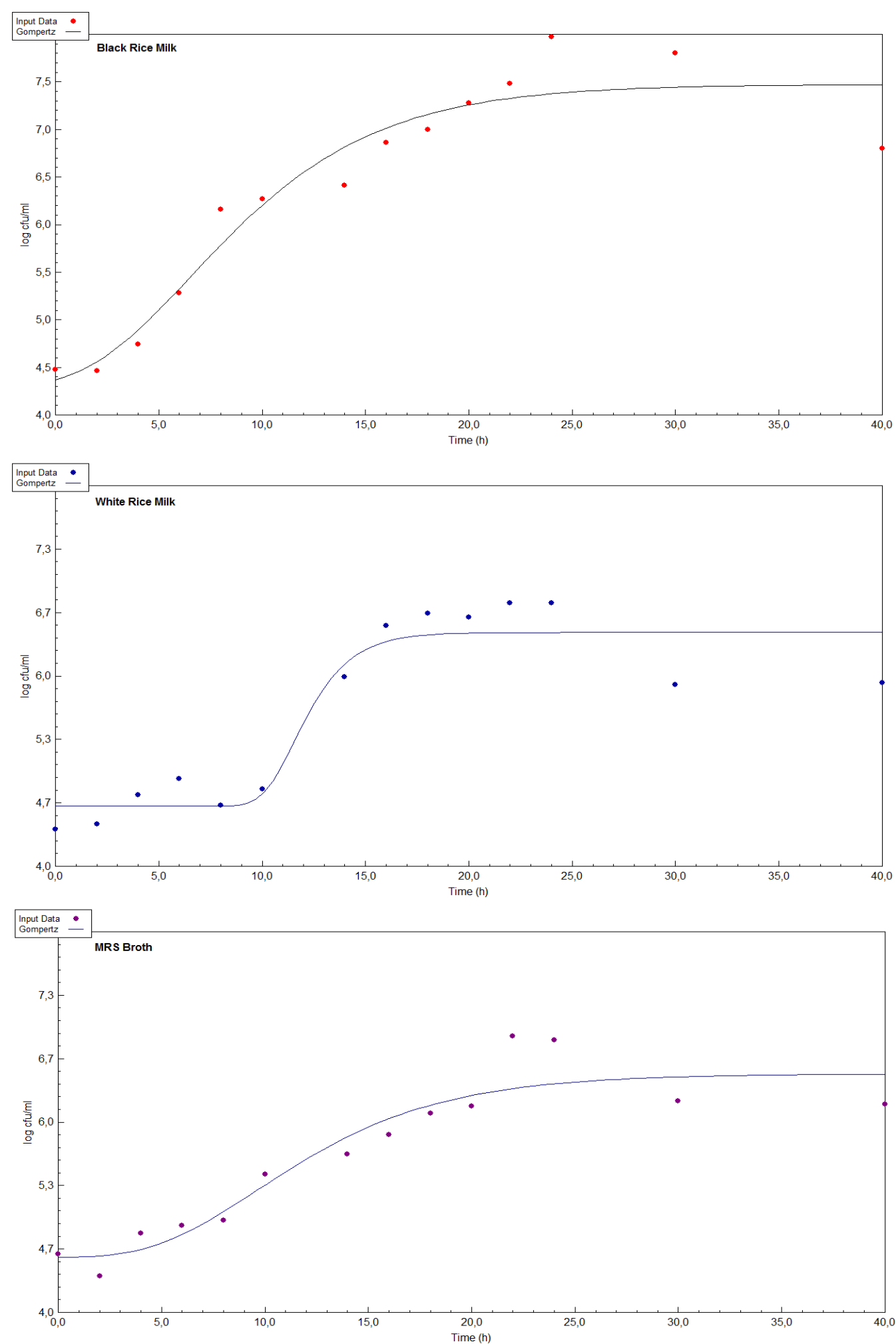

Figure 3. Fitting non-linear growth curves of $L$. acidophilus in black rice milk, white rice milk and MRS Broth to Gompertz equation 
Table 1. Growth kinetics of L. acidophilus in black rice milk, white rice milk, and MRS Broth incubated at $37^{\circ} \mathrm{C}$ calculated using Gompertz parameter values.

\begin{tabular}{lccccc}
\hline $\begin{array}{l}\text { Growth } \\
\text { medium }\end{array}$ & $\begin{array}{c}\text { Lag Phase } \\
\text { Duration }(\mathrm{h})\end{array}$ & $\begin{array}{c}\text { Generation } \\
\text { Time }(\mathrm{h})\end{array}$ & $\begin{array}{c}\text { Exponential } \\
\text { Growth Rate } \\
(\log \\
[\mathrm{CFU} / \mathrm{mL}] / \mathrm{h})\end{array}$ & $\begin{array}{c}\text { Maximum } \\
\text { Population } \\
\text { Density } \\
(\log \mathrm{CFU} / \mathrm{mL})\end{array}$ & $\begin{array}{c}\text { Coefficient of } \\
\text { Multiple } \\
\text { Determination } \\
\left(r^{2}\right)\end{array}$ \\
\hline $\begin{array}{l}\text { Black rice } \\
\text { milk }\end{array}$ & $1.45 \pm 0.17 a$ & $1.31 \pm 0.00 b$ & $0.23 \pm 0.00 a$ & $7.48 \pm 0.06 a$ & $0.93 \pm 0.01$ \\
$\begin{array}{l}\text { White rice } \\
\text { milk }\end{array}$ & $10.94 \pm 1.77 b$ & $0.58 \pm 0.16 a$ & $0.54 \pm 0.15 b$ & $6.64 \pm 0.12 b$ & $0.96 \pm 0.04$ \\
$\begin{array}{l}\text { MRS } \\
\text { Broth }\end{array}$ & $4.23 \pm 0.74 a$ & $2.22 \pm 0.18 c$ & $0.14 \pm 0.01 a$ & $6.46 \pm 0.08 b$ & $0.92 \pm 0.02$ \\
\hline
\end{tabular}

a-c Means followed by different letters in each column are significantly different $(P<0.05)$.

Generation time (GT) and Exponential Growth Rate (EGR) in MRS Broth were $2.22 \mathrm{~h}$ and 0.14 $\log (\mathrm{CFU} / \mathrm{mL}) / \mathrm{h}$, respectively (Table 1$)$. These results were consistent with the previous reports. Gupta et al. (1996) reported that the GTs of seven L. acidophilus strains in MRS Broth ranged from 1.97 to 3 h. The EGR of L. acidophilus LA5 strain in MRS Broth was recently calculated as 0.138 by Horackova et al. (2020). The GT in white rice milk was $0.58 \mathrm{~h}$, shorter than in black rice milk or MRS Broth $(P<0.05)$, which yielded higher EGR. As one may speculate, the higher carbohydrate content of white rice milk may have allowed a more rapid proliferation of $L$. acidophilus than black rice milk or MRS Broth. The highest Maximum Population Density (MPD) calculated using Gompertz equation parameters was reached in black rice milk $(P<0.05)$, which is approximately $1 \log$ higher than in white rice milk and MRS Broth that yielded similar MPD.

The growth kinetics of $L$. acidophilus in black rice milk, white rice milk and MRS Broth revealed that black rice supports the growth of this probiotic strain by shortening LPD and increasing MPD. This stimulative effect may stem from the chemical composition of black rice rich in phenolic compounds, mainly anthocyanins. Black rice bran has a higher content of protein, iron, fiber, phenolics, flavonoids, and anthocyanins and, therefore, higher antioxidant activity when compared to white rice bran (Zhang et al., 2010; Sangma and Parameshwari, 2021). Nurliani et al. (2015) used black rice extract and goat milk mixture for kefir production. They mentioned that the microorganisms in kefir grains could use the nutritional elements of black rice extract. The anthocyanins and anthocyanin monomers obtained from black rice showed prebiotic activity being metabolized into small molecules by bifidobacteria and lactobacilli (Zhu et al., 2010). Sun et al. (2018) reported that anthocyanins obtained from purple potatoes could increase the proliferation of probiotic cultures, including $L$. acidophilus. The enhanced biomass of $L$ acidophilus in liquid media added with grape pomace extract was reported by Hevert-Hernandez et al. (2009). According to the authors, some bacterial strains, such as Lactobacillus spp., could utilize phenolic compounds; namely, polyphenols contribute energy production of the cells.

The vitality and number of probiotic bacteria are critical factors for their beneficial functions in the host. The recommended level for probiotic bacteria is approximately $10^{6}-10^{8} \mathrm{CFU}$ per $\mathrm{g}-\mathrm{mL}$ of the probiotic product (Shah, 2001). Figure 4 shows the survival of $L$. acidophilus in black rice milk and white rice milk during storage at $4^{\circ} \mathrm{C}$ for 20 days following incubation at $37^{\circ} \mathrm{C}$ for $24 \mathrm{~h}$. First 7 days of the storage period, L. acidophilus count decreased by $1.84 \log$ units $(\mathrm{p}<0.05)$ but showed small reductions during the rest of the storage $(P>0.05)$. The total reduction in black rice milk was $2.11 \log$ units with a final count of 5.62 $\log \mathrm{CFU} / \mathrm{mL}$. On the other hand, the $L$. acidophilus population in white rice milk reduced by $2.51 \log$ units in 14 days $(P<0.05)$ and then reached $4.32 \log \mathrm{CFU} / \mathrm{mL}$ with a small increase $(P>0.05)$ at the end of the storage period. 


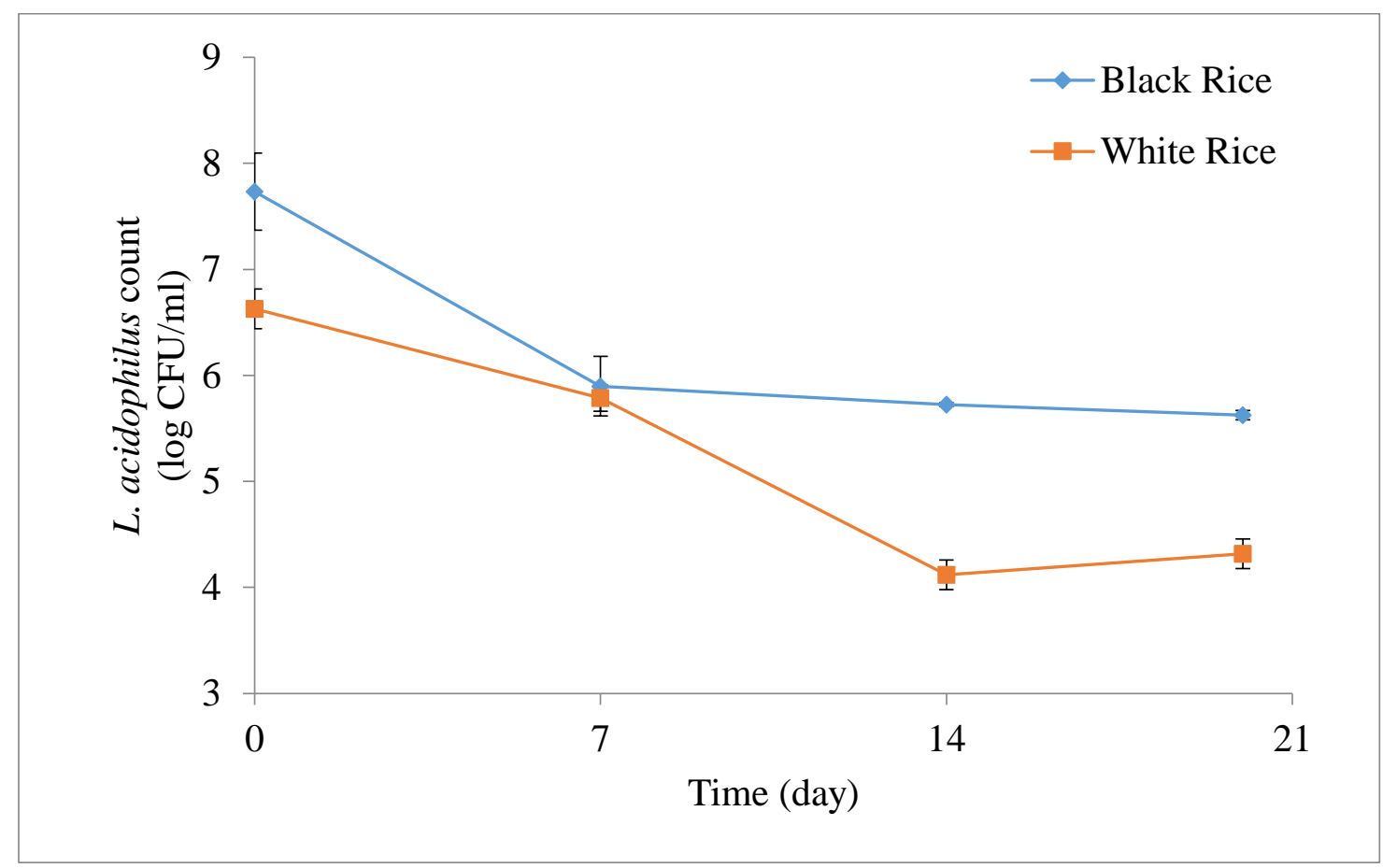

Figure 4. Survival of L. acidophilus in black rice and white rice milk during storage at $4^{\circ} \mathrm{C}$

Özcan et al. (2010) reported approximately $1 \log$ reduction in $L$. acidophilus LA5 count in rice pudding stored at $4{ }^{\circ} \mathrm{C}$ for 21 days. In a study by Hasani et al. (2016), the L acidophilus population inoculated into yogurt decreased by $0.84 \log$ $\mathrm{CFU} / \mathrm{g}$ during refrigerated storage for 28 days. In contrast, rice bran addition $(\% 0.3-1.2)$ increased the viability of this probiotic strain. The current study results show that black rice milk is slightly more effective than white rice milk to support the survival of $L$. acidophilus during refrigerated storage.

\section{CONCLUSION}

If the food matrix supports the growth and survival of probiotic bacteria, the efficacy of these beneficial microorganisms may be enhanced. Therefore the current study provides comparative knowledge on the growth kinetics of L. acidophilus in black rice milk, white rice milk and MRS Broth. The main conclusion is that black rice milk shortens lag phase duration and increases the maximum population density of $L$. acidophilus. Furthermore, black rice milk provides a better environment for the growth of $L$. acidophilus with its lower $\mathrm{pH}$ value than white rice milk, which is close to optimum $\mathrm{pH}$ for the growth of this probiotic bacterium. On the other hand, black rice milk slightly supports the survival of $L$. acidophilus during cold storage compared to white rice milk. Therefore, black rice milk can be a good alternative to cow milk to produce probiotic products for people with cow's milk allergies and vegans.

\section{ACKNOWLEDGEMENT}

This study was supported by the Commission of Scientific Research Projects of Sakarya University (Project Number: 2020-7-25-98).

\section{CONFLICT OF INTEREST}

The authors certify that they have no affiliations with or involvement in any organization or entity with any financial or non-financial interest in the subject matter or materials discussed in this manuscript.

\section{AUTHORS CONTRIBUTIONS}

S.Coşansu: Conceptualization, methodology, planning, data analysis, writing and editing; S.Toupal: Experimental analysis, data analysis and writing; Ö.Aslan: Experimental analysis. 


\section{REFERENCES}

Aleixandre-Tudó, J.L., Castelló-Cogollos, L., Aleixandre, J.L., Aleixandre-Benavent, R. (2020). Tendencies and challenges in worldwide scientific research on probiotics. Probiotics Antimicrob Proteins, 12(3): 785-797.

Anonymous (2021). MRS Broth. https://www.sigmaaldrich.com/TR/en/product /sial/69966\# (Accessed October 4, 2021).

Belewu, M.A., Abdulsalam, K.O., Belewu, K., Belewu, N. (2013). Rice-Coconut Yoghurt: preparation, nutritional and sensory qualities. Asian J Agric Rural Dev, 3(393-2016-23802): 924928.

Coman, M.M., Oancea, A.M., Verdenelli, M.C., Cecchini, C., Bahrim, G.E., Orpianesi, C., Cresci, A., Silvi, S. (2018). Polyphenol content and in vitro evaluation of antioxidant, antimicrobial and prebiotic properties of red fruit extracts. Eur Food Res Technol, 244(4):735-745.

Cremon, C., Barbaro, M.R., Ventura, M., Barbara, G. (2018). Pre-and probiotic overview. Curr Opin Pharmacol, 43: 87-92.

De Paulo Farias, D., de Araujo, F.F., Neri-Numa, I.A., Pastore, G.M. (2019). Prebiotics: Trends in food, health and technological applications. Trends Food Sci Technol, 93: 23-35.

Deng, Y., Misselwitz, B., Dai, N., Fox, M. (2015). Lactose intolerance in adults: biological mechanism and dietary management. Nutrients, 7(9): 8020-8035.

FAO/WHO (2001). Evaluation of health and nutritional properties of probiotics in food including powder milk with live lactic acid bacteria. Report of a Joint FAO/WHO Expert Consultation. [Online]. Available: $\mathrm{ftp}: / / \mathrm{ftp}$. fao.org/es/esn/food/probio report en.pdf

Figueroa-González, I., Cruz-Guerrero, A., Quijano, G. (2011). The benefits of probiotics on human health. J Microbial Biochem Tecbnol S, 1: 1948-5948.

Gibson, A.M., Bratchell, N., Roberts, T.A. (1987). The effect of sodium chloride and temperature on the rate and extent of growth of Clostridium botulinum type A in pasteurized pork slurry. J Appl Bacteriol, 62: 479-490.

Gomes, A.M., Malcata, F.X. (1999). Bifidobacterium spp. and Lactobacillus acidophilus: biological, biochemical, technological and therapeutical properties relevant for use as probiotics. Trends Food Sci Technol, 10(4-5): 139-157.

Gupta, P.K., Mital, B.K., Garg, S.K. (1996). Characterization of Lactobacillus acidophilus strains for use as dietary adjunct. Int J Food Microbiol, 29(1): 105-109.

Hasani, S., Khodadadi, I., Heshmati, A. (2016). Viability of Lactobacillus acidophilus in rice bran enriched stirred yoghurt and the physicochemical and sensory characteristics of product during refrigerated storage. Int J Food Sci Technol, 51(11): 2485-2492.

Hester, S.N., Mastaloudis, A., Gray, R., Antony, J.M., Evans, M., Wood, S.M. (2018). Efficacy of an anthocyanin and prebiotic blend on intestinal environment in obese male and female subjects. $J$ Nutr Metab, 2018: 1-11. https://doi.org/10.1155/ 2018/7497260

Hervert-Hernández, D., Pintado, C., Rotger, R., \& Goñi, I. (2009). Stimulatory role of grape pomace polyphenols on Lactobacillus acidophilus growth. Int J Food Microbiol, 136(1): 119-122.

Hidalgo, M., Oruna-Concha, M.J., Kolida, S., Walton, G.E., Kallithraka, S., Spencer, J.P., de Pascual-Teresa, S. (2012). Metabolism of anthocyanins by human gut microflora and their influence on gut bacterial growth. I Agric Food Chem, 60(15): 3882-3890.

Horackova, S., Vesela, K., Klojdova, I., Bercikova, M., Plockova, M. (2020). Bile salt hydrolase activity, growth characteristics and surface properties in Lactobacillus acidophilus. Eur Food Res Technol, 246: 1627-1636.

Indira, M., Venkateswarulu, T.C., Peele, K.A., Bobby, M.N., Krupanidhi, S. (2019). Bioactive molecules of probiotic bacteria and their mechanism of action: a review. 3 Biotech, 9(8): 111.

Ito, V.C., Lacerda, L.G. (2019). Black rice (Oryza sativa L.): A review of its historical aspects, 
chemical composition, nutritional and functional properties, and applications and processing technologies. Food Chem, 301: 125304.

Khoo, H.E., Azlan, A., Tang, S.T., Lim, S.M. (2017). Anthocyanidins and anthocyanins: colored pigments as food, pharmaceutical ingredients, and the potential health benefits. Food Nutr Res, 61(1): 1361779.

Ozcan, T., Yilmaz-Ersan, L., Akpinar-Bayizit, A., Sahin, O.I., Aydinol, P. (2010). Viability of Lactobacillus acidophilus LA-5 and Bifidobacterium bifidum BB-12 in Rice Pudding. Mljekarstvo/Dairy, 60(2): 135-144

Pallah, O.V., Meleshko, T.V., Bati, V.V., Boyko, N.V. (2019). Extracts of edible plants stimulators for beneficial microorganisms. Biotechnol Acta, 12(3): 67-74.

Panghal, A., Janghu, S., Virkar, K., Gat, Y., Kumar, V., Chhikara, N. (2018). Potential nondairy probiotic products-A healthy approach. Food Biosci, 21: 80-89.

Pimentel, T.C., da Costa, W.K.A., Barão, C.E., Rosset, M., Magnani, M. (2021). Vegan probiotic products: A modern tendency or the newest challenge in functional foods. Food Res Int, 140: 110033.

Sangma, H.C.R., Parameshwari, S. (2021). Health benefits of black rice (Zizania aqatica)-a review. Mater Today: Proc, https://doi.org/10.1016/ j.matpr.2021.07.257

Schillinger, U., Holzapfel, W.H. (2012). Culture media for lactic acid bacteria. In: Handbook of Culture Media for Food and Water Microbiology, Curtis,
G.D.W., Baird, R.M., Corry, J.E. (Eds.), 3 ${ }^{\text {rd }}$ edition, Royal Society of Chemistry, pp. 174-192.

Shah, N.P. (2001). Functional foods from probiotics and prebiotics: Functional Foods from Probiotics and Prebiotics. Food Technol (Chicago), 55(11): 46-53.

Sun, H., Zhang, P., Zhu, Y., Lou, Q., He, S. (2018). Antioxidant and prebiotic activity of five peonidin-based anthocyanins extracted from purple sweet potato (Ipomoea batatas (L.) Lam.). Sci Rep, 8(1): 1-12.

Swinnen, I.A.M., Bernaerts, K., Dens, E.J., Geeraerd, A.H., Van Impe, J.F. (2004). Predictive modelling of the microbial lag phase: a review. Int J Food Microbiol, 94(2): 137-159.

Tangyu, M., Muller, J., Bolten, C.J., Wittmann, C. (2019). Fermentation of plant-based milk alternatives for improved flavour and nutritional value. Appl Microbiol Biotechnol, 103(23): 92639275 .

Zhang, M.W., Zhang, R.F., Zhang, F.X., Liu, R.H. (2010). Phenolic profiles and antioxidant activity of black rice bran of different commercially available varieties. J Agric Food Chem, 58(13): 75807587.

Zhu, Y., Sun, H., He, S., Lou, Q., Yu, M., Tang, M., Tu, L. (2018). Metabolism and prebiotics activity of anthocyanins from black rice (Oryza sativa L.) in vitro. PLoS One, 13(4): e0195754. 